\title{
Modified Hargreaves-Samani Equation for the Assessment of Reference Evapotranspiration in Alpine River Basins
}

\author{
Giovanni Ravazzani' ${ }^{1}$ Chiara Corbari²; Stefano Morella ${ }^{3}$; Paride Gianoli4; and Marco Mancini ${ }^{5}$
}

\begin{abstract}
Deriving accurate estimates of reference evapotranspiration is required for water resource management, irrigation water requirement computations, and successful hydrological modeling. The Food and Agricultural Organization of the United Nations (FAO) recommended the Penman-Monteith equation as the standard for estimating reference evapotranspiration. An alternative method for application at sites where only air temperature measurements are available is the Hargreaves-Samani equation. The primary objective of this study is to investigate the possibility for application of the Hargreaves-Samani equation in alpine areas for computing daily reference evapotranspiration. An evaluation of the Hargreaves-Samani equation and its modifications proposed in literature is made by comparing daily estimates with Penman-Monteith results at 51 meteorological stations in the Upper Po River Basin (Italy) and the Rhone River Basin (Switzerland). Significant error was encountered in all methods using the Hargreaves-Samani equation. A relationship for adjusting the Hargreaves-Samani coefficient on the basis of local elevation is proposed, calibrated, and validated. The resulting modified Hargreaves-Samani equation showed a significant reduction of error for estimating daily reference evapotranspiration. The proposed equation is not intended for replacement of the Penman-Monteith method but for application in alpine rivers when only air temperature data are available. DOI: 10.1061/(ASCE)IR.19434774.0000453. ( ) 2012 American Society of Civil Engineers.
\end{abstract}

CE Database subject headings: Evapotranspiration; River basins; Water resources; Irrigation; Hydrologic models.

Author keywords: Reference evapotranspiration; Modified Hargreaves-Samani equation; Alpine river basins.

\section{Introduction}

Reference evapotranspiration $\left(E T_{0}\right)$ is defined as the potential evapotranspiration of a hypothetical surface of green grass of uniform height, actively growing, completely shading the ground, and adequately watered. Accurate estimates of $E T_{0}$ are key elements for efficient water resource management, for designing and scheduling irrigation systems, and for environmental assessment $(\mathrm{Xu}$ and $\mathrm{Li}$ 2003; Xu and Singh 2005; Diodato and Bellocchi 2007).

Many methods can be used for estimating $E T_{0}$ (Gong et al. 2006). The Penman-Monteith method (FAO-56 PM) is recommended by the food and Agriculture Organization of the United Nations (FAO) as the sole method to calculate $E T_{0}$ whenever the required input data are available (Allen et al. 1998; Droogers and Allen 2002). The FAO-56 PM is a physically based approach that can be used globally without any need for additional

\footnotetext{
${ }^{1}$ Assistant Professor, Dept. of Hydraulics, Environmental and Surveying Engineering, Politecnico di Milano, Milan, Italy (corresponding author). E-mail: giovanni.ravazzani@polimi.it

${ }^{2}$ Postdoctoral Researcher, Dept. of Hydraulics, Environmental and Surveying Engineering, Politecnico di Milano, Milan, Italy. E-mail: chiara .corbari@mail.polimi.it

${ }^{3}$ Student, Politecnico di Milano, Milan, Italy. E-mail: stefano.morella@ mail.polimi.it

${ }^{4}$ Student, Politecnico di Milano, Milan, Italy. E-mail: paride.gianoli@ mail.polimi.it

${ }^{5}$ Professor, Dept. of Hydraulics, Environmental and Surveying Engineering, Politecnico di Milano, Milan, Italy. E-mail: marco.mancini@ polimi.it

Note. This manuscript was submitted on July 2, 2011; approved on December 15, 2011; published online on December 20, 2011. Discussion period open until December 1, 2012; separate discussions must be submitted for individual papers. This paper is part of the Journal of Irrigation and Drainage Engineering, Vol. 138, No. 7, July 1, 2012. CASCE, ISSN 0733-9437/2012/7-592-599/\$25.00.
}

adjustments of parameters. It requires measurement of air temperature, air relative humidity, solar radiation, and wind speed. The number of meteorological stations where all of these parameters are observed is limited in many areas of the globe, especially in developing countries (Droogers and Allen 2002).

A research topic in which FAO-56 PM can exhibit a limited application is the study of the effects of the climate change on the hydrological cycle of small river basins. In this context, it is difficult to find reliable meteorological forcings required by FAO-56 $\mathrm{PM}$ at a spatial and temporal resolution adequate for the dimension of investigated river basins. Moreover, the necessity to analyze long time series of meteorological forcings requires the use of computationally efficient algorithms to speed up simulations.

The lack of data motivated Hargreaves and Samani (1985) to develop an alternative approach to $E T_{0}$ computation [referred to in this paper as the Hargreaves-Samani (HS) model] using daily maximum and minimum air temperature data as the only input. Parsimoniousness of the HS model permits easy implementation within geographic information systems for spatial prediction of $E T_{0}$ (Buttafuoco et al. 2010).

Several studies have shown that the HS model may provide reliable estimates of $E T_{0}$ for 5 days or longer time steps (Jensen et al. 1997; Droogers and Allen 2002; Hargreaves and Allen 2003). Shuttleworth (1993) recommends that the HS model should not be used for shorter period than 1 month. Issues related to overestimation of HS model under humid condition was reported by Temesgen et al. (2005) and Trajkovic (2005). It has also been shown that HS equation tends to overestimate $E T_{0}$ at low evapotranspiration rates and to underestimate it in very dry and windy regions (Amatya et al. 1995; Droogers and Allen 2002; Xu and Singh 2002).

Several studies attempted to improve accuracy of the HS equation, primarily adjusting the equation coefficients to local conditions (Trajkovic 2007; Vanderlinden et al. 2004). 
The aim of this study is to provide an analysis of HS-based methods for application on complex alpine river basins at daily time scale. A modification of the HS model that takes into consideration elevation is proposed to reduce error in daily $E T_{0}$ estimates. The new method is developed for its inclusion in a distributed hydrological model (Rabuffetti et al. 2008; Corbari et al. 2009), with the purpose of investigating the effect of climate change on water availability and quality in alpine river basins. In the next section, the study area is described, which includes the data set of meteorological observations. A brief review of methods for $E T_{0}$ estimation is then presented. Following, an analysis is undertaken to evaluate the accuracy of the HS equation and its modifications proposed in literature. Next, a correction of the HS equation that accounts for local elevation is proposed, which include calibration and validation, and finally, in the last section, summary and conclusions are drawn.

\section{Study Area and Weather Data Source}

The study was carried out in predominantly alpine regions in Italy (the Upper Po River) and Switzerland (the Rhone River), located between the meridians $7-9.5^{\circ} \mathrm{W}$ and the parallels $44-46.5^{\circ} \mathrm{N}$. Climate conditions are typically humid, characterized by more precipitation in autumn and spring and a dry season in winter, with snowfall over the mountains.

The Upper Po River Basin occupies an extension of approximately $38,000 \mathrm{~km}^{2}$, with an elevation range of 58-4,600 $\mathrm{m}$ above sea level. The Rhone River Basin has an area of approximately $5,300 \mathrm{~km}^{2}$ and an elevation range of 380-4,600 m above sea level.

The data set used in this analysis was obtained from the database of the Regional Monitoring Service of Regione Piemonte (Italy) and Meteoswiss (Switzerland). Data from 2000-2008 were used for the study. From hourly data, daily minimum and maximum temperature, incoming shortwave radiation, wind speed, and relative humidity were computed, excluding those stations at which time series showed too many errors. A total of 40 stations on the River Po and 11 stations on the Rhone River Basin were selected for this study (Fig. 1). A temperature-humidity probe and wind sensors are placed 2 and $10 \mathrm{~m}$ above the surface, respectively. The wind speed measurements were converted to wind speed at $2-\mathrm{m}$ height by applying the wind profile relationship introduced in Chapter 3 of FAO Irrigation and Drainage paper 56 (Allen et al. 1998).

Site elevations range from $77-3,580 \mathrm{~m}$ above mean sea level. Table 1 shows a summary of weather data of meteorological stations and corresponding site elevations. The results range from -4.3 to $20.2^{\circ} \mathrm{C}$ for the maximum air temperature $\left(T_{\max }\right),-8.9$ to $10.1^{\circ} \mathrm{C}$ for minimum air temperature $\left(T_{\min }\right), 58.8-80.9 \%$ for

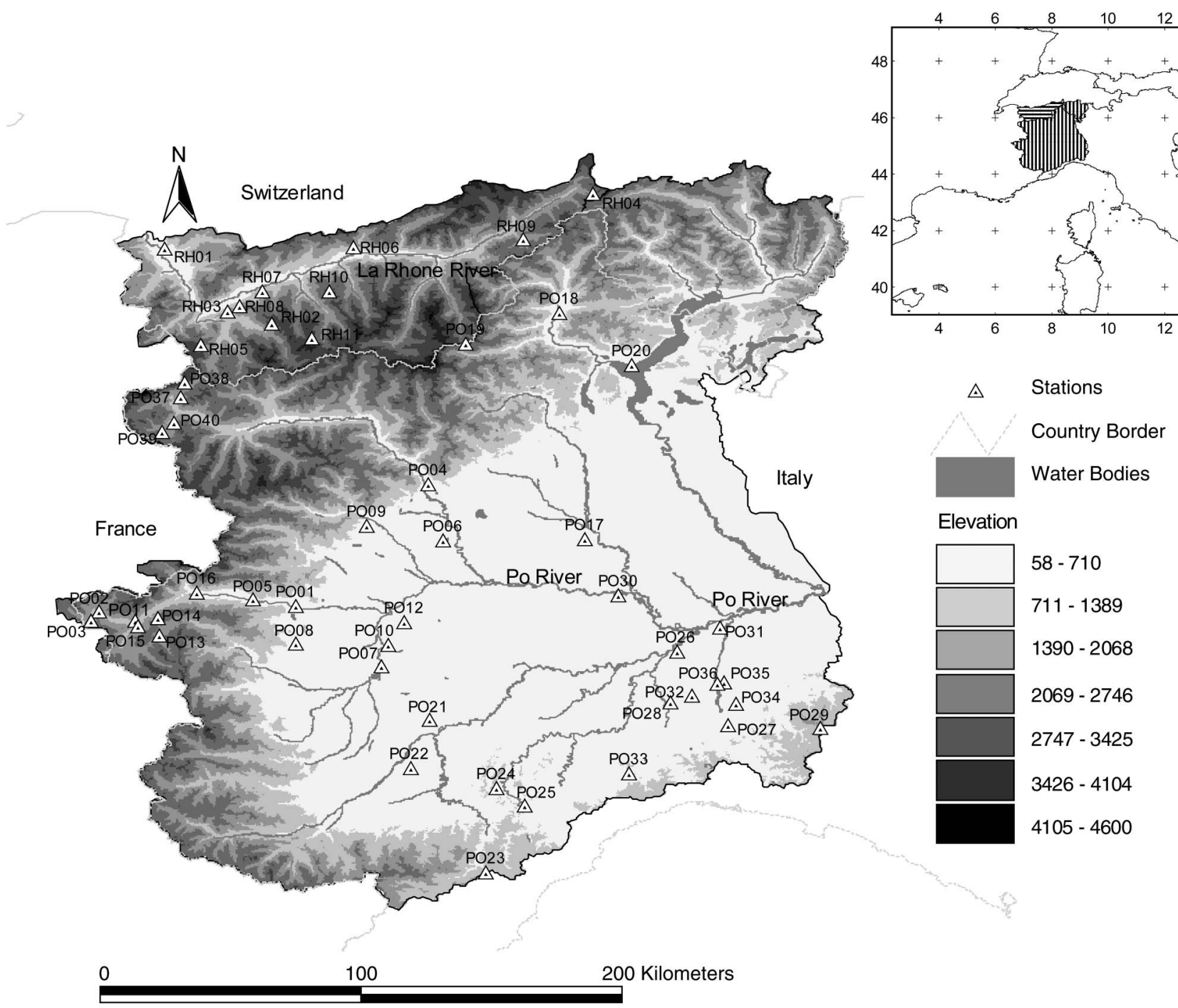

Fig. 1. Locations of meteorological stations in this study 
Table 1. Summary of Weather Station Sites in this Study

\begin{tabular}{|c|c|c|c|c|c|c|c|c|c|c|c|c|}
\hline \multirow[b]{2}{*}{ Station } & \multirow[b]{2}{*}{ Code } & \multirow[b]{2}{*}{ Altitude (m) } & \multicolumn{2}{|c|}{$T_{\max }\left({ }^{\circ} \mathrm{C}\right)$} & \multicolumn{2}{|c|}{$T_{\min }\left({ }^{\circ} \mathrm{C}\right)$} & \multicolumn{2}{|c|}{$\mathrm{RH}(\%)$} & \multicolumn{2}{|c|}{$U_{2}(\mathrm{~m} / \mathrm{s})$} & \multicolumn{2}{|c|}{$R\left(\mathrm{~W} / \mathrm{m}^{2}\right)$} \\
\hline & & & $\mu$ & $\sigma$ & $\mu$ & $\sigma$ & $\mu$ & $\sigma$ & $\mu$ & $\sigma$ & $\mu$ & $\sigma$ \\
\hline Avigliana & PO01 & 340 & 18.3 & 8.6 & 6.2 & 7.4 & 80.7 & 13.0 & 1.6 & 1.0 & 150.2 & 92.7 \\
\hline Prerichard & PO02 & 1,353 & 12.7 & 7.7 & 3.3 & 6.1 & 66.1 & 20.0 & 1.8 & 0.9 & 158.1 & 92.9 \\
\hline Bardonecchia & PO03 & 1,791 & 3.9 & 7.1 & 0.5 & 4.6 & 66.9 & 17.5 & 1.2 & 0.7 & 147.6 & 99.2 \\
\hline Borgofranco d'Ivrea & PO04 & 337 & 17.3 & 8.9 & 9.8 & 7.6 & 73.3 & 16.8 & 2.3 & 1.1 & 160.0 & 93.9 \\
\hline Borgone & PO05 & 400 & 17.8 & 8.3 & 6.0 & 6.8 & 77.9 & 15.4 & 1.9 & 0.9 & 149.6 & 93.5 \\
\hline Candia & PO06 & 226 & 16.6 & 7.9 & 6.3 & 7.2 & 60.7 & 19.8 & 0.6 & 0.5 & 148.3 & 100.0 \\
\hline Carmagnola & PO07 & 232 & 18.5 & 9.1 & 6.6 & 7.4 & 75.6 & 18.5 & 1.1 & 0.4 & 156.5 & 98.5 \\
\hline Cumiana & PO08 & 327 & 18.6 & 9.3 & 8.1 & 7.1 & 64.4 & 17.7 & 1.2 & 0.4 & 155.8 & 96.0 \\
\hline Belmonte & PO09 & 687 & 16.0 & 8.5 & 9.3 & 6.9 & 70.1 & 17.8 & 2.1 & 1.1 & 149.4 & 95.0 \\
\hline Bauducchi & PO10 & 226 & 18.2 & 9.0 & 7.9 & 7.5 & 77.5 & 15.1 & 1.3 & 0.6 & 151.8 & 97.2 \\
\hline $\mathrm{Gad}$ & PO11 & 1,065 & 14.8 & 7.9 & 5.1 & 7.4 & 76.8 & 13.0 & 3.7 & 1.2 & 170.0 & 97.0 \\
\hline Pino Torinese & PO12 & 608 & 14.3 & 7.5 & 5.6 & 5.6 & 72.5 & 17.1 & 1.8 & 0.8 & 90.9 & 66.6 \\
\hline Pragelato & PO13 & 1,620 & 4.9 & 8.6 & 1.1 & 4.5 & 70.8 & 16.4 & 1.9 & 0.8 & 168.1 & 94.4 \\
\hline Le Selle & PO14 & 1,980 & 14.8 & 9.3 & 8.0 & 7.6 & 71.1 & 22.6 & 1.7 & 1.0 & 154.9 & 91.8 \\
\hline Sauze d'Oulx & PO15 & 1,373 & 2.8 & 6.5 & 0.3 & 3.7 & 76.2 & 16.3 & 2.2 & 1.0 & 180.7 & 109.1 \\
\hline Pietrastretta & PO16 & 520 & 16.5 & 7.7 & 9.2 & 6.8 & 66.0 & 17.3 & 2.9 & 1.6 & 158.9 & 94.5 \\
\hline Vercelli & PO17 & 132 & 15.7 & 10.1 & 5.9 & 8.5 & 65.8 & 19.7 & 1.6 & 0.7 & 151.8 & 99.5 \\
\hline Domodossola & PO18 & 252 & 13.8 & 10.7 & 4.1 & 8.7 & 65.9 & 19.0 & 1.4 & 0.8 & 142.0 & 97.1 \\
\hline Passo del Moro & PO19 & 2,820 & 0.9 & 5.4 & -3.6 & 5.7 & 69.8 & 16.3 & 2.7 & 1.4 & 139.4 & 85.9 \\
\hline Pallanza & PO20 & 202 & 17.8 & 9.7 & 9.0 & 8.0 & 74.3 & 21.5 & 1.5 & 0.8 & 147.6 & 97.8 \\
\hline Bra & PO21 & 285 & 18.7 & 9.4 & 8.8 & 7.2 & 71.9 & 14.8 & 1.1 & 0.4 & 157.3 & 98.0 \\
\hline Fossano & $\mathrm{PO} 22$ & 403 & 17.2 & 8.6 & 8.6 & 7.0 & 78.4 & 16.3 & 2.2 & 0.6 & 155.4 & 95.2 \\
\hline Colle san Bernardo & $\mathrm{PO} 23$ & 980 & 12.4 & 7.5 & 6.8 & 6.9 & 62.8 & 21.0 & 5.5 & 2.3 & 138.0 & 89.8 \\
\hline Mombarcaro & $\mathrm{PO} 24$ & 896 & 13.3 & 7.7 & 7.8 & 6.7 & 79.4 & 12.7 & 3.8 & 1.3 & 153.3 & 91.1 \\
\hline Bergalli & $\mathrm{PO} 25$ & 385 & 17.3 & 7.4 & 5.9 & 6.6 & 68.2 & 20.8 & 1.3 & 0.7 & 124.0 & 80.5 \\
\hline Alessandria & $\mathrm{PO} 26$ & 90 & 16.2 & 10.3 & 5.6 & 7.7 & 80.8 & 12.9 & 2.0 & 0.8 & 153.0 & 102.8 \\
\hline Arquata Scrivia & $\mathrm{PO} 27$ & 325 & 17.4 & 9.2 & 8.4 & 7.0 & 69.5 & 16.0 & 1.4 & 0.6 & 102.4 & 69.5 \\
\hline Basaluzzo & PO28 & 128 & 18.6 & 9.7 & 9.5 & 7.7 & 58.8 & 18.8 & 1.4 & 0.6 & 175.3 & 103.3 \\
\hline Capanne di Cosola & PO29 & 1,550 & 11.8 & 9.1 & 5.3 & 7.0 & 67.2 & 17.4 & 4.9 & 2.5 & 159.2 & 96.0 \\
\hline Casale Monferrato & PO30 & 118 & 16.0 & 9.4 & 8.1 & 7.7 & 79.5 & 12.4 & 1.7 & 0.7 & 150.7 & 99.8 \\
\hline Isola S. Antonio & PO31 & 77 & 20.2 & 10.1 & 10.1 & 7.4 & 67.9 & 18.8 & 1.3 & 0.8 & 161.2 & 106.0 \\
\hline Novi Ligure & PO32 & 167 & 20.0 & 9.8 & 9.6 & 7.2 & 80.9 & 12.1 & 1.1 & 0.6 & 154.6 & 103.7 \\
\hline Ponzone Bric Berton & PO33 & 773 & 15.3 & 8.9 & 8.7 & 7.0 & 66.3 & 18.2 & 3.0 & 1.5 & 158.9 & 101.9 \\
\hline Sardigliano & PO34 & 228 & 17.1 & 9.1 & 9.0 & 7.1 & 76.8 & 13.2 & 2.2 & 1.3 & 161.9 & 104.8 \\
\hline Spineto Scrivia & PO35 & 187 & 18.8 & 9.8 & 8.1 & 7.0 & 73.0 & 18.2 & 1.7 & 0.9 & 149.8 & 106.0 \\
\hline Castellar Ponzano & PO36 & 146 & 15.8 & 10.1 & 5.6 & 7.8 & 73.2 & 14.8 & 1.9 & 1.1 & 150.7 & 103.1 \\
\hline Mont de la Sax & PO37 & 2,300 & 7.0 & 7.4 & 0.4 & 7.1 & 65.9 & 20.9 & 1.7 & 1.4 & 166.6 & 103.3 \\
\hline Ferrachet & PO38 & 2,365 & 2.2 & 5.3 & -0.3 & 4.4 & 75.3 & 14.8 & 1.3 & 1.1 & 161.5 & 99.2 \\
\hline La Gran Tete & PO39 & 2,430 & 2.6 & 6.0 & 0.2 & 4.2 & 76.8 & 13.9 & 2.2 & 1.9 & 172.0 & 101.8 \\
\hline Foillex & PO40 & 2,060 & 2.5 & 5.8 & 0.0 & 4.5 & 67.6 & 16.6 & 1.5 & 1.0 & 150.9 & 101.8 \\
\hline Aigle & RH01 & 381 & 14.8 & 8.0 & 6.4 & 6.5 & 77.6 & 9.5 & 1.9 & 0.87 & 144.7 & 91.1 \\
\hline Evolene & RH02 & 1,825 & 8.2 & 7.6 & 1.4 & 6.4 & 64.1 & 17.0 & 1.4 & 0.53 & 163.8 & 91.1 \\
\hline Fey & RH03 & 737 & 14.4 & 8.6 & 7.1 & 6.8 & 62.9 & 13.8 & 2.8 & 1.34 & 146.5 & 98.5 \\
\hline Grimsel & RH04 & 1,980 & 5.0 & 7.7 & -0.2 & 6.9 & 72.5 & 18.4 & 5.1 & 1.46 & 148.2 & 94.1 \\
\hline Gd St Bernard & RH05 & 2,472 & 2.2 & 7.3 & -2.5 & 6.7 & 74.6 & 19.3 & 5.2 & 2.37 & 156.0 & 101.9 \\
\hline Jungfrau & RH06 & 3580 & -4.3 & 6.4 & -8.9 & 6.7 & 70.3 & 21.5 & 7.2 & 4.12 & 175.3 & 103.7 \\
\hline Montana & RH07 & 1,508 & 10.2 & 8.1 & 2.8 & 6.6 & 67.0 & 15.0 & 1.8 & 0.94 & 161.5 & 93.5 \\
\hline Sion & RH08 & 482 & 16.1 & 8.8 & 6.0 & 7.1 & 69.5 & 11.8 & 2.1 & 0.92 & 158.0 & 95.9 \\
\hline Ulrichen & RH09 & 1,345 & 10.1 & 9.3 & -1.4 & 8.4 & 75.3 & 10.9 & 1.6 & 1.12 & 149.7 & 95.7 \\
\hline Visp & RH10 & 640 & 15.3 & 9.6 & 4.8 & 7.2 & 67.5 & 13.0 & 2.9 & 2.09 & 151.8 & 100.6 \\
\hline Zermatt & RH11 & 1,638 & 9.7 & 8.1 & 0.6 & 6.6 & 65.0 & 15.0 & 1.9 & 0.72 & 154.7 & 86.4 \\
\hline
\end{tabular}

Note: $T_{\max }=$ maximum daily temperature; $T_{\min }=$ minimum daily temperature; $\mathrm{RH}=$ relative humidity; $U_{2}=$ wind speed at 2-m height; $R=$ shortwave radiation; $\mu=$ mean value; and $\sigma=$ standard deviation. 
relative humidity $(\mathrm{RH}), 0.6-7.2 \mathrm{~m} / \mathrm{s}$ for wind speed $\left(U_{2}\right)$, and 90.9-180.7 W/ $\mathrm{m}^{2}$ for radiation $(R)$.

Fig. 2 shows mean values of meteorological forcings plotted against station elevation. Minimum and maximum air temperatures, as expected, are strongly correlated to elevation $\left(r^{2}=0.75\right.$ and $r^{2}=0.86$, respectively), wind speed shows moderate correlation $\left(r^{2}=0.24\right)$, and relative humidity and shortwave radiation result are not correlated to elevation $\left(r^{2}=0.014\right.$ and $r=0.074$, respectively). The difference between maximum daily temperature and minimum daily temperature reduces progressively as elevation increases [Fig. 2(a)].

\section{Methods for Estimation of Reference Evapotranspiration}

\section{FAO-56 Penman-Monteith Equation}

The FAO-56 PM equation for calculating daily $E T_{0}$ (Allen et al. 1998) is

$$
E T_{0, P M}=\frac{0.408 \Delta\left(R_{n}-G\right)+\gamma \frac{900}{T+273} U_{2}\left(e_{s}-e_{a}\right)}{\Delta+\gamma\left(1+0.34 U_{2}\right)}
$$

where $E T_{0, P M}=E T_{0}$ estimated by the FAO-56 PM equation $\left(\mathrm{mm} /\right.$ day); $R_{n}=$ net radiation $\left(\mathrm{MJ} / \mathrm{m}^{2} /\right.$ day); $G=$ soil heat flux $\left(\mathrm{MJ} / \mathrm{m}^{2} /\right.$ day); $T=$ average daily air temperature at $2-\mathrm{m}$ height $\left({ }^{\circ} \mathrm{C}\right) ; U_{2}=$ wind speed at $2-\mathrm{m}$ height $\left(\mathrm{m} \mathrm{s}^{-1}\right) ; e_{s}=$ saturation vapor pressure $(\mathrm{kPa}) ; e_{a}=$ actual vapor pressure $(\mathrm{kPa}) ; \Delta=$ slope of the saturated water-vapor pressure curve $\left(\mathrm{kPa}^{\circ} \mathrm{C}^{-1}\right)$; and $\gamma=$ psychrometric constant $\left(\mathrm{kPa}^{\circ} \mathrm{C}^{-1}\right)$. The computation of all data required for the calculation of the $E T_{0}$ followed the method given in Chapter 3 of FAO Irrigation and Drainage Paper 56 (Allen et al. 1998).

\section{Hargreaves-Samani Equation}

The HS equation for calculating daily $E T_{0}$ (Hargreaves and Samani 1985) is

$$
E T_{0, H S}=H C \cdot R_{a} \cdot\left(T_{\max }-T_{\min }\right)^{H E}\left(\frac{T_{\max }+T_{\min }}{2}+H T\right)
$$

where $E T_{0, \mathrm{HS}}=E T_{0}$ estimated by the HS equation $(\mathrm{mm} /$ day); $R_{a}=$ extraterrestrial radiation $\left(\mathrm{mm} /\right.$ day); $T_{\max }=$ daily maximum air temperature $\left({ }^{\circ} \mathrm{C}\right) ; T_{\min }=$ daily minimum air temperature $\left({ }^{\circ} \mathrm{C}\right)$; $H C=$ empirial coefficient $(H C=0.0023) ; H E=$ empirical exponent $(H E=0.5)$; and $H T=$ a factor needed to convert units of Fahrenheit to Celsius $(H T=32 / 1.8=17.8)$ (Hargreaves 1994). Eq. (2) uses the average daily air temperature in combination with extraterrestrial radiation as an indicator of the incoming global radiation. Moreover, the daily temperature range is related to relative humidity and cloudiness (Hargreaves and Samani 1982; Samani and Pessarakli 1986; Shuttleworth 1993; Di Stefano and Ferro 1997). The HS equation was developed to estimate grass $E T_{0}$ for the growing season and is thus theoretically not valid for the dormant season unless sufficient accuracy is ascertained by specific analysis.

Several studies were addressed to improve accuracy of the HS equation. Allen (1993) attempted to improve upon Eq. (2) by fitting
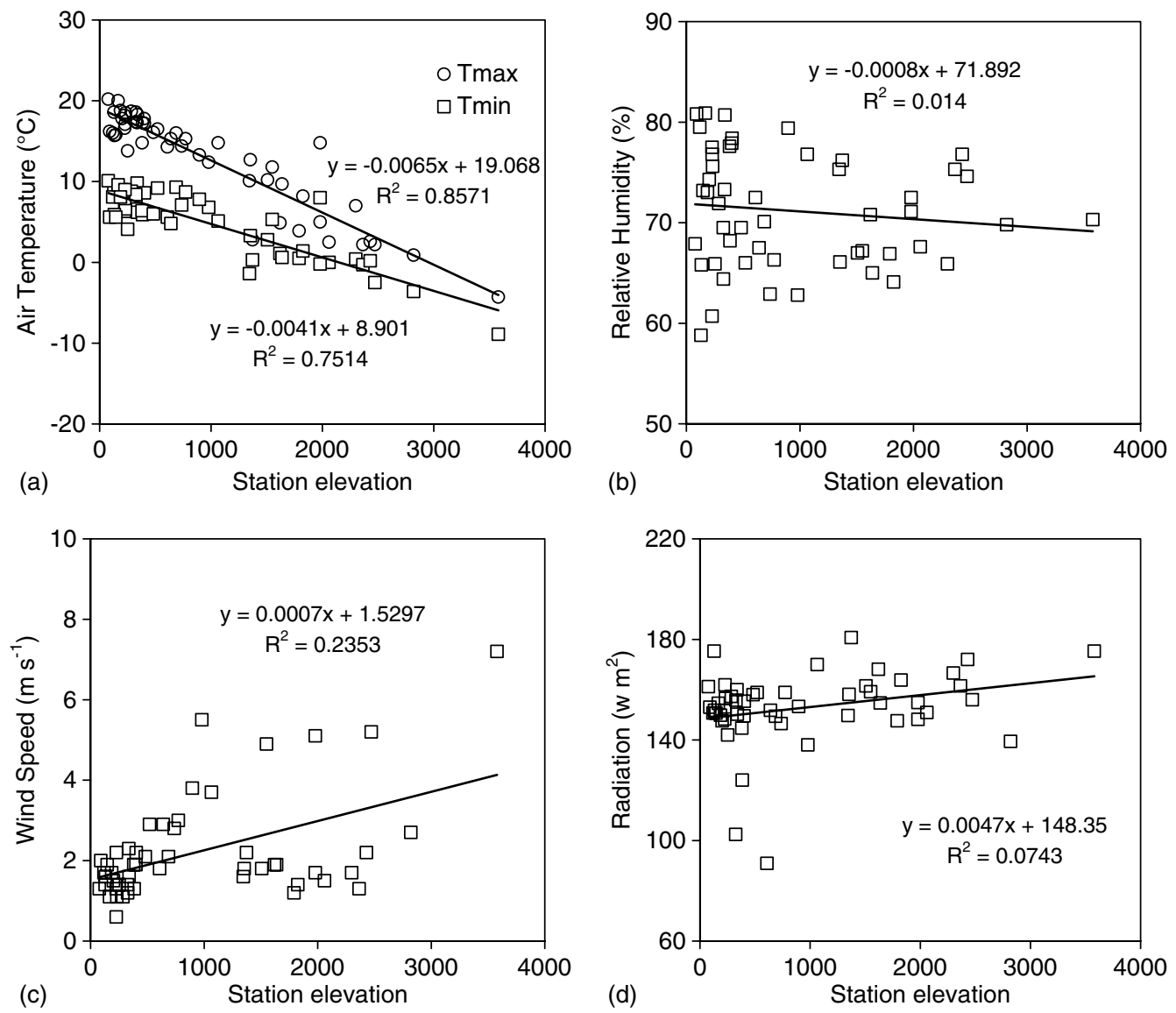

Fig. 2. Mean values of meteorological forcings as a function of station elevation: (a) minimum and maximum air temperature; (b) relative humidity; (c) wind speed; and (d) shortwave radiation 
coefficients on the basis of monthly calculations of $E T_{0}$ by the FAO-56 PM. For this purpose, he used the FAO Climwat data set (Smith 1993) comprised of 3,200 stations and lysimeter measurements of $E T_{0}$ from Davis, CA. The result was the following form for the HS equation, in which $H C=0.0030, H E=0.4$, and $H T=20$ :

$$
E T_{0, \mathrm{HSA}}=0.0030 \cdot R_{a} \cdot\left(T_{\max }-T_{\min }\right)^{0.4}\left(\frac{T_{\max }+T_{\min }}{2}+20\right)
$$

where $E T_{0, \mathrm{HSA}}=E T_{0}$ estimated by the HS equation modified by Allen (1993) (mm/ day). However, the improvement in accuracy of this form of the HS equation relative to the FAO-56 PM was less than $3 \%$.

Adjustment of the HS coefficients and exponent to local conditions is an alternative way to improve $E T_{0}$ estimation. Vanderlinden et al. (2004), on the basis of 16 weather stations within the region of Andalusia (Spain), proposed a linear relationship between an adjusted $H C$ and the ratio of the average temperature $\bar{T}$ to the average daily temperature range $\overline{\Delta T}$, leading to equation

$$
\begin{aligned}
E T_{0, \mathrm{HSV}}= & \left(0.0005 \frac{\bar{T}}{\overline{\Delta T}}+0.00159\right) \cdot R_{a} \\
& \cdot\left(T_{\max }-T_{\min }\right)^{0.5}\left(\frac{T_{\max }+T_{\min }}{2}+17.8\right)
\end{aligned}
$$

where $E T_{0, \mathrm{HSV}}+E T_{0}$ estimated by the HS equation modified by Vanderlinden et al. (2004) ( $\mathrm{mm} /$ day). The authors showed a decrease of root-mean-square error (RMSE) of $24 \%$ after adjusting the coefficients.

Trajkovic (2007), calibrated the HS exponent using weather measurements from 10 stations in the western Balkan region (southeast Europe), obtaining a reduction of overestimation of mean annual $E T_{0}$ from $22 \%$ to $1 \%$. The result was the following form for the HS equation, in which $H E=0.424$ :

$$
E T_{0, \mathrm{HST}}=0.0023 \cdot R_{a} \cdot\left(T_{\max }-T_{\min }\right)^{0.424}\left(\frac{T_{\max }+T_{\min }}{2}+17.8\right)
$$

where $E T_{0, \mathrm{HST}}=E T_{0}$ estimated by the HS equation modified by Trajkovic (2007) (mm/ day).

Among other modifications of the HS equation, Samani (2000) proposed a correction factor on the basis of fitting a second-order polynomial relationship against average monthly temperature difference from 65 weather stations located $7-50^{\circ} \mathrm{N}$ latitude in the United States.

\section{Evaluation of Hargreaves-Samani Equation-Based Methods}

Evaluation of the original HS equation and modified methods is presented. Goodness of fit indexes are computed against $E T_{0}$ calculated with the FAO-56 PM equation, which was chosen as a benchmark in this study.

\section{Evaluation Parameters}

For evaluation of the $E T_{0}$ estimates, the mean bias error (MBE) and the RMSE were computed as follows (Willmott 1982):

$$
\begin{gathered}
\mathrm{MBE}=\frac{\sum_{i=1}^{n}\left(E T_{0, H S x}^{i}-E T_{0, P M}^{i}\right)}{n} \\
\mathrm{RMSE}=\left[\frac{\sum_{i=1}^{n}\left(E T_{0, H S x}^{i}-E T_{0, P M}^{i}\right)^{2}}{n}\right]^{0.5}
\end{gathered}
$$

where $E T_{0, \mathrm{HS} x}^{i}=i$ th $E T_{0}$ estimated with the HS equation or one of its modified versions; $E T_{0, \mathrm{PM}}^{i}=i$ th $E T_{0}$ estimated with the FAO-56 PM equation; and $n=$ sample size.

\section{Evaluation of Hargreaves-Samani Method}

The FAO-56 PM and HS models were used to estimate daily $E T_{0}$ for the entire study period (Jan. 1, 2000 until Dec. 31, 2008). The $E T_{0, H S}$ was then compared with $E T_{0, P M}$.

Table 2 shows evaluation parameters of the HS equation computed for the Upper Po River Basin, the Rhone River Basin, and the two river basins together. The MBE denotes overestimation $(0.154 \mathrm{~mm} /$ day $)$ for the Upper Po and underestimation $(-0.145 \mathrm{~mm} /$ day) for the Rhone, which nearly cancels out (0.079 mm/ day) when considering all stations in a single group. The RMSEs are $0.885 \mathrm{~mm} /$ day and $0.67 \mathrm{~mm} /$ day, respectively, for the Upper Po and for the Rhone River Basins.

Fig. 3 shows the relationship between the HS MBE and elevation for all stations considered in this study. It is generally found that the HS equation overestimates evapotranspiration at low elevation, whereas underestimation is observed at higher elevations. Two possible causes can explain these results. First, the HS equation

\begin{tabular}{|c|c|c|c|c|}
\hline & Hargreaves-Samani & Vanderlinden et al. & Trajkovic & Allen \\
\hline \multicolumn{5}{|c|}{ Upper Po River Basin } \\
\hline Mean bias error $(\mathrm{mm})$ & 0.154 & 0.272 & -0.244 & 0.320 \\
\hline Root-mean-square error (mm) & 0.885 & 0.996 & 0.845 & 0.912 \\
\hline \multicolumn{5}{|c|}{ Rhone River Basin } \\
\hline Mean bias error (mm) & -0.145 & -0.252 & -0.430 & 0.033 \\
\hline Root-mean-square error (mm) & 0.670 & 0.770 & 0.765 & 0.654 \\
\hline \multicolumn{5}{|c|}{ Upper Po and Rhone River Basins } \\
\hline Mean bias error (mm) & 0.079 & 0.139 & -0.291 & 0.248 \\
\hline Root-mean-square error $(\mathrm{mm})$ & 0.836 & 0.944 & 0.825 & 0.854 \\
\hline
\end{tabular}
uses the temperature difference to indirectly estimate solar radiation and was calibrated using data from Davis, CA, with an average temperature difference of approximately $14{ }^{\circ} \mathrm{C}$. In areas in which

Table 2. Evaluation Parameters of Hargreaves-Samani Equation and Modified Versions Proposed by Vanderlinden et al. (2004), Trajkovic (2007), and Allen (1993) Computed for Upper Po River Basin, Rhone River Basin, and Entire Area 


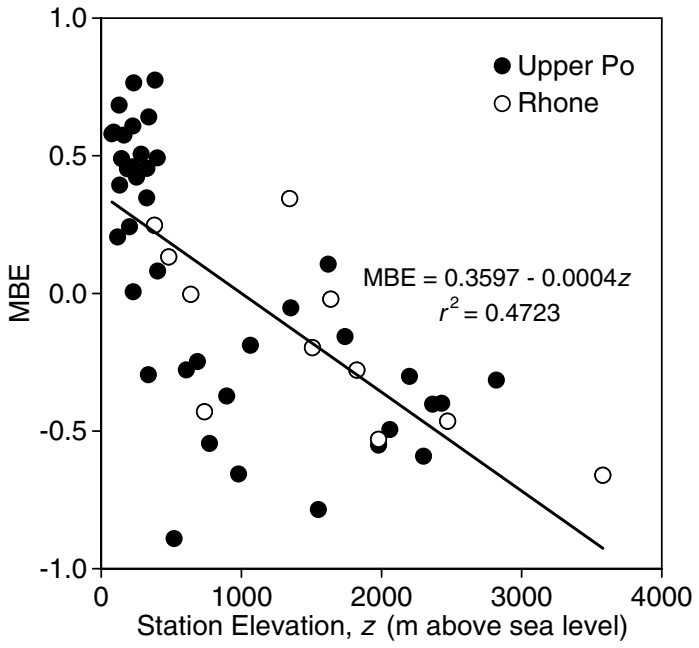

Fig. 3. Relationship between Hargreaves-Samani mean bias error and station elevation

the temperature difference is less, it is expected that the HS equation underestimates radiation, thus underestimating $E T_{0}$ (Samani 2000). In the case of alpine river basins, a high temperature difference at low altitude produced an $E T_{0}$ overestimation, whereas at higher elevation, $E T_{0}$ is underestimated owing to the reduced temperature difference. In addition, results are in agreement with considerations regarding wind speed correlation with elevation, as shown in Fig. 2, and general behavior of the HS model, which underestimates $E T_{0}$ in windy locations.

\section{Evaluation of Modified Hargreaves-Samani Methods}

Poor results achieved by the HS equation in estimating $E T_{0}$ on the Upper Po and Rhone River Basins suggest use of modified versions of the equation to increase accuracy. In this respect, modified equations by Allen (1993) [Eq. (3)], Vanderlinden et al. (2004) [Eq. (4)], and Trajkovic (2007) [Eq. (5)] were tested against FAO-56 PM for the same study period considered in evaluating the HS equation (Jan.1, 2000 until Dec. 31, 2008). The modified version proposed by Samani (2000) was also tested, but, because it gave worse outcomes than other approaches, results are not presented in this paper for the sake of brevity.

Evaluation parameters for the Upper Po River Basin, the Rhone River Basin, and the two river basins together are shown in Table 2. For the Upper Po River Basin, the three modified equations show greater MBE with respect to the original HS equation: overestimation for Vanderlinden et al. (2004) and Allen (1993) (0.272 and 0.320 , respectively); underestimation for Trajkovic (2007) $(-0.244)$. Similar results are shown for RMSE, which is greater than the HS model estimated, except for the Trajkovic (2007) equation, which shows $0.845 \mathrm{~mm} /$ day.

For the Rhone River Basin, only the Allen (1993) equation shows an improvement with respect to the original HS model

Table 3. Evaluation Parameters of Modified Hargreaves-Samani Equation Proposed in this Study Computed for Upper Po River Basin, Rhone River Basin, and Entire Area

\begin{tabular}{lccc}
\hline & $\begin{array}{c}\text { Upper Po } \\
\text { River Basin }\end{array}$ & $\begin{array}{c}\text { Rhone } \\
\text { River Basin }\end{array}$ & $\begin{array}{c}\text { Upper Po and } \\
\text { Rhone River Basins }\end{array}$ \\
\hline Mean bias error (mm) & -0.030 & 0.031 & -0.014 \\
Root-mean-square & 0.784 & 0.655 & 0.754 \\
error (mm) & & & \\
\hline
\end{tabular}

for $\mathrm{MBE}$ and RMSE, with are, respectively, $0.033 \mathrm{~mm} /$ day and $0.654 \mathrm{~mm} /$ day.

When considering all stations in a single group, no method is clearly better than others; the Trajkovic (2007) equation shows lower RMSE $(0.825 \mathrm{~mm} /$ day $)$ but greater MBE $(-0.291 \mathrm{~mm} /$ day $)$.

\section{Correction of Hargreaves-Samani Equation for Alpine Basins}

The general tendency of the HS equation to overestimate evapotranspiration at low elevation and underestimate it at higher elevations in the studied river basins suggests that a possible solution to improve the HS equation's performance in estimating $E T_{0}$ is the adjustment of station elevation, as already introduced by Annandale et al. (2002). To calibrate the HS equation on the basis of the FAO-56 PM method, a correction factor using two calibrating coefficients, $c_{0}$ and $c_{1}$, was introduced into the HS equation

$$
E T_{0, H S M}=\left(c_{0}+c_{1} z\right) E T_{0, H S}
$$

where $E T_{0, H S M}=E T_{0}$ computed with the modified equation; and $z=$ station elevation ( $\mathrm{m}$ above sea level). Coefficients in Eq. (8) were determined by choosing $c_{0}$ and $c_{1}$ to minimize MBE on stations belonging to the Upper Po River Basin. The algorithm adopted for optimization was the generalized reduced gradient, a nonlinear extension of the simplex method for linear programming (Lasdon et al. 1978). The values of the best fit calibrating parameters are 0.817 for $c_{0}$ and 0.00022 for $c_{1}$. The final modified equation to compute $E T_{0}$ can then be rewritten

$$
\begin{aligned}
E T_{0, H S M}= & (0.817+0.00022 \cdot z) \cdot H C \cdot R_{a} \\
& \cdot\left(T_{\max }-T_{\min }\right)^{H E}\left(\frac{T_{\max }+T_{\min }}{2}+H T\right)
\end{aligned}
$$

To validate the modified HS model, Eq. (9) was applied on stations belonging to the Rhone River Basin. Evaluation parameters MBE and RMSE, shown in Table 3, were computed for the Upper Po River Basin, the Rhone River Basin, and the two river basins together. The correction factor introduced in the HS equation led to improvement in $E T_{0}$ estimation. The $\mathrm{MBE}$ for the Upper Po and the Rhone River Basins reduced to $-0.030 \mathrm{~mm} /$ day and

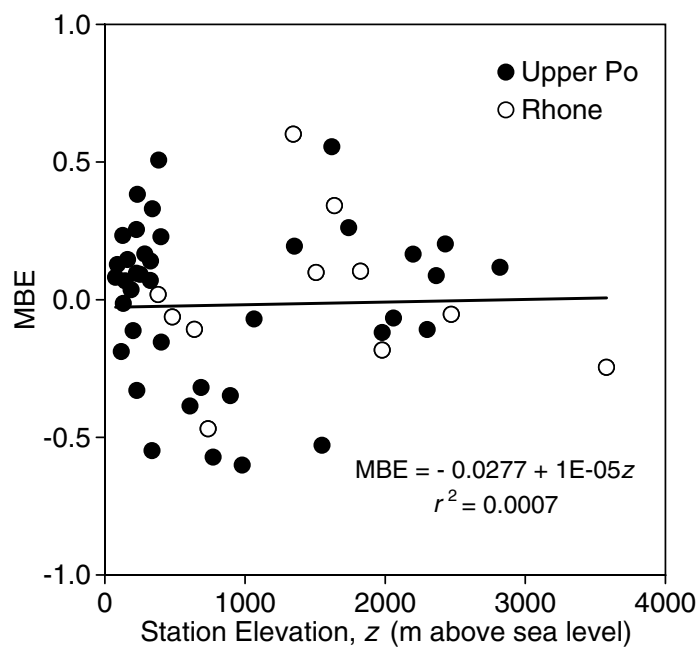

Fig. 4. Relationship between modified Hargreaves-Samani mean bias error and station elevation 

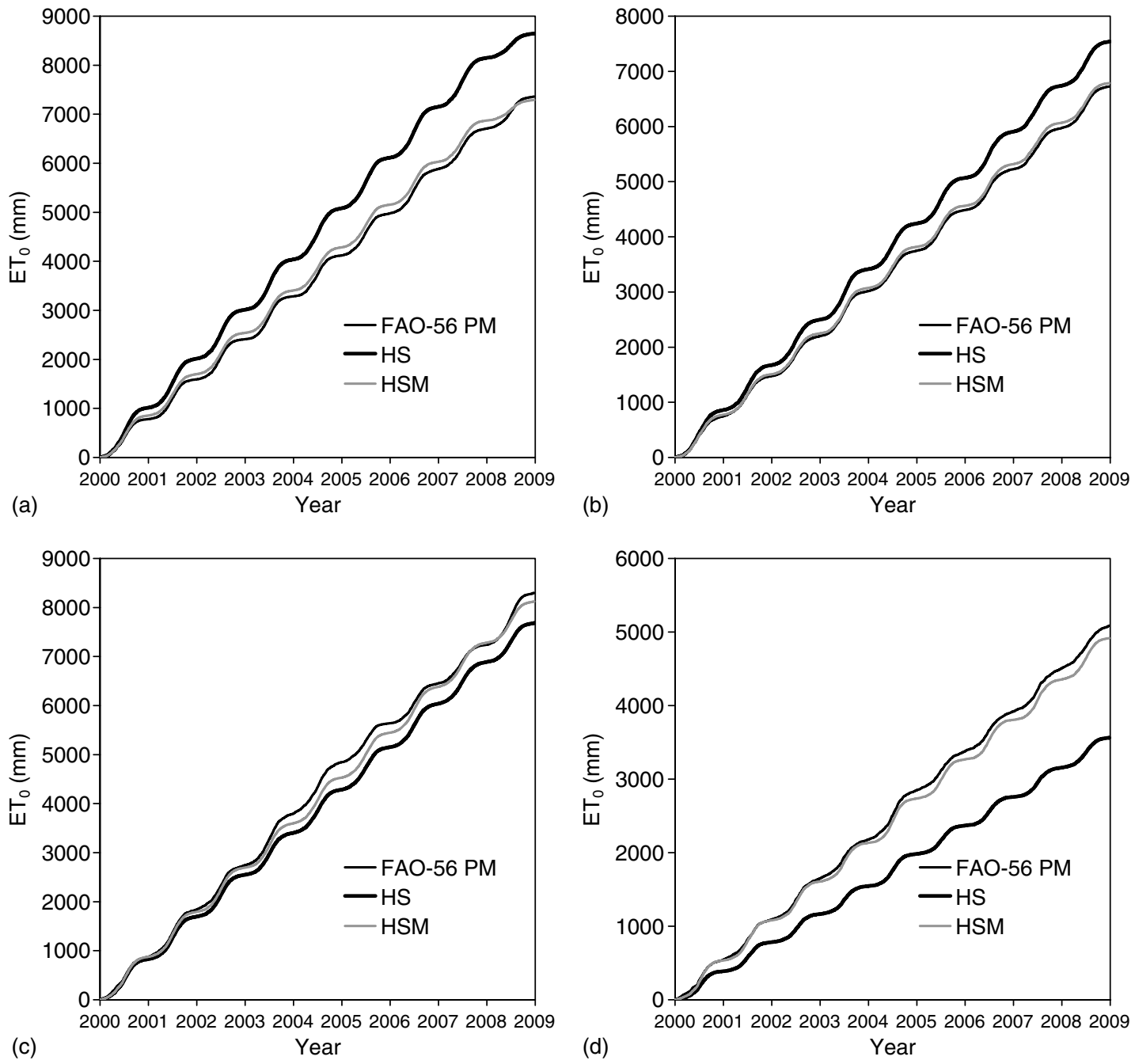

Fig. 5. Comparison of evolution of cumulative $E T_{0}$ according to FAO-56 Penman-Monteith (FAO-56 PM), Hargreaves-Samani (HS), and Hargreaves-Samani modified (HSM) method in four stations: (a) Vercelli, (b) Aigle, (c) Gad, and (d) Gd St Bernard

$0.031 \mathrm{~mm}$ /day, respectively. The RMSE was $0.784 \mathrm{~mm} /$ day and $0.655 \mathrm{~mm} /$ day, respectively, for the Upper Po and for the Rhone River Basins, thus obtaining even better results on the validation data set. The modified HS equation was more accurate with respect to the original equation and to the other modified versions tested in this study, showing a reduction of nearly $10 \%$ in RMSE on the entire area with respect to the original HS equation.

Fig. 4 shows the relationship between the HS MBE and elevation for all stations considered in this study. The optimization procedure performed to minimize the MBE led to a nearly complete elimination of correlation between MBE and station elevation.

Fig. 5 shows the relative comparison of the evolution of cumulative $E T_{0}$ at four representative stations according to FAO-56 PM, HS and modified HS model. HS equation shows underestimation at the two stations at higher elevation (Gad, Gd St Bernard) and overestimation at the two stations at lower elevation (Vercelli, Aigle). The modified HS equation shows good performance.

\section{Summary and Conclusions}

The FAO-56 PM equation is recommended as the standard for calculating $E T_{0}$, but its application is limited by the availability of required meteorological data. In these circumstances, the HS equation on the basis of minimum and maximum air temperature is considered a good alternative, but adjustment of empirical coefficients to local climatic conditions is often required, keeping FAO-56 PM as a benchmark.

The HS equation was compared with the FAO-56 PM equation for daily time steps for 40 stations within the Upper Po River Basin and 11 stations within the Rhone River Basin on, respectively, the Italian and Swiss Alps. Results show a general overestimation at lower elevation and underestimation at windier stations at higher elevation.

Application of modified versions of the HS equation proposed in the literature does not improve significantly or even worsen performances.

Starting from the considerations that MBE was correlated to station elevation, an equation was proposed to compute $E T_{0}$ by including a correction factor on the basis of two empirical coefficients and local elevation in the standard HS equation. The two empirical coefficients were calibrated against FAO-56 PM, minimizing MBE on stations belonging to the Upper Po River Basin. The optimization procedure led to a nearly complete elimination of correlation between MBE and station elevation. The new modified equation showed improvement in estimating $E T_{0}$ and was confirmed by validation performed on stations belonging to the Rhone River Basin. 
An advantage of new equation is that it can be easily implemented into distributed hydrological models because it requires only availability of a digital elevation model, in addition to the meteorological data required by standard HS equation. In addition, because the equation was tested against daily data for the entire study period, its application is not limited to growing season, as the original HS equation is.

The proposed equation is not intended for replacement of the FAO-56-PM method but for application in alpine rivers when only air temperature data are available. The approach presented in this study could be applied in other regions for calibrating a correction factor in which correlation between elevation and wind speed, in turn correlated to MBE, could be observed.

\section{Acknowledgments}

The work was supported in the framework of the ACQWA EU/FP7 project (Grant No. 212250) "Assessing Climate impacts on the Quantity and quality of Water"; the ACCA project, in collaboration with the University of Milan, "Misura e modellazione matematica dei flussi di ACqua e CArbonio negli agro-ecosistemi a mais"; and the PREGI project "Previsione meteo idrologica per la gestione irrigua," funded by Regione Lombardia. The authors thank ARPA Regione Piemonte and MeteoSwiss for providing the meteorological data.

\section{References}

Allen, R. G. (1993). "Evaluation of a temperature difference method for computing grass reference evapotranspiration." Report to Water Resources Development and Management Service, Land and Water Development Division, Food and Agricultural Organization of the United Nations (FAO), Rome.

Allen, R. G., Pereira, L. S., Raes, D., and Smith, M. (1998). "Crop evapotranspiration: Guidelines for computing crop water requirements." Food and Agricultural Organization of the United Nations (FAO) Irrigation and Drainage Paper 56, FAO, Rome.

Amatya, D. M., Skaggs, R. W., and Gregory, J. D. (1995). "Comparison of methods for estimating REF-ET." J. Irrig. Drain. Eng., 121(6), 427-435.

Annandale, J. C., Jovanovic, N. Z., Benadè, N., and Allen, R. G. (2002). "Software for missing data error analysis of Penman-Monteith reference evapotranspiration." Irrig. Sci., 21(2), 57-67.

Buttafuoco, G., Caloiero, T., and Coscarelli, R. (2010). "Spatial uncertainty assessment in modelling reference evapotranspiration at regional scale." Hydrol. Earth Syst. Sci., 14(11), 2319-2327.

Corbari, C., Martinelli, J., Ravazzani, G., and Mancini, M. (2009). "Elevation based correction of snow coverage retrieved from satellite images to improve model calibration." Hydrol. Earth Syst. Sci., 13(5), 639-649.

Di Stefano, C., and Ferro, V. (1997). "Estimation of evapotranspiration by Hargreaves formula and remote sensed data in semi-arid Mediterranean areas." J. Agric. Eng. Res., 68(3), 189-199.

Diodato, N., and Bellocchi, G. (2007). "Modeling reference evapotranspiration over complex terrains from minimum climatological data." Water Resour. Res., 43(5), W05444.
Droogers, P., and Allen, R. G. (2002). "Estimating reference evapotranspiration under inaccurate data conditions." Irrig. Drain. Syst., 16(1), $33-45$.

Gong, L., Xu, C.-Y., Chen, D., Halldin, S., and Chen, Y. D. (2006). "Sensitivity of the Penman-Monteith reference evapotranspiration to key climatic variables in the Changjiang (Yangtze River) Basin." J. Hydrol. (Amsterdam), 329(3-4), 620-629.

Hargreaves, G. H. (1994). "Defining and using reference evapotranspiration.” J. Irrig. Drain. Eng., 120(6), 1132-1139.

Hargreaves, G. H., and Allen, R. G. (2003). "History and evaluation of Hargreaves evapotranspiration equation." J. Irrig. Drain. Eng., 129(1), 53-63.

Hargreaves, G. H., and Samani, Z. A. (1982). "Estimating potential evapotranspiration." J. Irrig. and Drain. Div., 108(3), 225-230.

Hargreaves, G. H., and Samani, Z. A. (1985). "Reference crop evapotranspiration from temperature." Appl. Eng. Agric., 1(2), 96-99.

Jensen, D. T., Hargreaves, G. H., Temesgen, B., and Allen, R. G. (1997). "Computation of ETo under nonideal conditions." J. Irrig. Drain. Eng., 123(5), 394-400.

Lasdon, L. S., Waren, A. D., Jain, A., and Ratner, M. (1978). "Design and testing of a generalized reduced gradient code for nonlinear programming." ACM Trans. Math. Software, 4(1), 34-50.

Rabuffetti, D., Ravazzani, G., Corbari, C., and Mancini, M. (2008). "Verification of operational quantitative discharge forecast (QDF) for a regional warning system: The AMPHORE case studies in the upper Po River." Nat. Hazards Earth Syst. Sci., 8(1), 161-173.

Samani, Z. (2000). "Estimating solar radiation and evapotranspiration using minimum climatological data." J. Irrig. Drain. Eng., 126(4), 265-267.

Samani, Z. A., and Pessarakli, M. (1986). "Estimating potential crop evapotranspiration with minimum data in Arizona." Trans. ASAE, 29(2), $522-524$.

Shuttleworth, W. J. (1993). "Evaporation." Handbook of hydrology, D. R. Maidment, ed., McGraw-Hill, New York.

Smith, M. (1993). "CLIMWAT for CROPWAT: A climatic database for irrigation planning and management." Food and Agricultural Organization of the United Nations (FAO) Irrigation and Drainage Paper 49, FAO, Rome.

Temesgen, B., Eching, S., Davidoff, B., and Frame, K. (2005). "Comparison of some reference evapotranspiration equations for California." J. Irrig. Drain. Eng., 131(1), 73-84.

Trajkovic, S. (2005). "Temperature-based approaches for estimating reference evapotranspiration." J. Irrig. Drain. Eng., 131(4), 316-323.

Trajkovic, S. (2007). "Hargreaves versus Penman-Monteith under humid conditions." J. Irrig. Drain. Eng., 133(1), 38-42.

Vanderlinden, K., Giraldez, J. V., and Van Meirvenne, M. M. (2004). "Assessing reference evapotranspiration by the Hargreaves method in southern Spain.” J. Irrig. Drain. Eng., 130(3), 184-191.

Willmott, C. J. (1982). "Some comments on the evaluation of model performance." Bull. Am. Meteorol. Soc., 63(11), 1309-1313.

$\mathrm{Xu}$, C. Y., and Singh, V. P. (2002). "Cross comparison of empirical equations for calculating potential evapotranspiration with data from Switzerland." Water Resour. Manage., 16(3), 197-219.

Xu, C. Y., and Singh, V. P. (2005). "Evaluation of three complementary relationship evapotranspiration models by water balance approach to estimate actual regional evapotranspiration in different climatic regions." J. Hydrol. (Amsterdam), 308(1-4), 105-121.

Xu, Z. X., and Li, J. Y. (2003). "A distributed approach for estimating catchment evapotranspiration: Comparison of the combination equation and the complementary relationship approaches." Hydrol. Processes, 17(8), 1509-1523. 